\title{
PUZZLES IN THE COMPARATIVE STUDY OF FRONTIERS: PROBLEMS, SOME SOLUTIONS, AND METHODOLOGICAL IMPLICATIONS ${ }^{1}$
}

\author{
Thomas D. Hall \\ Department of Sociology and Anthropology \\ DePauw University \\ thall@depauw.edu
}

\begin{abstract}
This paper examines ways in which world-system analysis can be employed fruitfully to explore frontier social processes. Conversely, it also examines how frontier social processes and events can be very valuable explorations of highly localized processes - geographically and temporally - of world-systems. The study of frontier regions can help to uncover the ways in which many worldsystemic contexts shape local human agency. Conversely, the study of these highly localized human practices offers ways to gain insights to how individual actions constantly reconstruct world-systems. Finally, many of the lessons learned here with respect to frontiers, especially in regard to ethnic and national identity formation and transformation can be extended to other social concerns.
\end{abstract}

\section{INTRODUCTION}

At first, frontiers may seem like an odd topic to explore comparative methods for world-systems analysis. Some might argue that with globalization there are few if any frontiers left. Some might even go so far as to argue frontiers no longer have an impact on the contemporary world. Both arguments are wrong, but not transparently so.

The initial issue is what are we discussing? What is a frontier? This is a very frustrating question as there are almost as many definitions of frontiers as there are people who have studied them! I begin with a working definition. A frontier is a zone, where two different social systems nonstate societies, state societies, and even world-systems come into more-or-less sustained contact (Hall 2005a). Of course, this definition is vague. That is intentional. It is a starting definition to which refinements might, and later will be added. A frontier is not a border our boundary between two states - though that is how the term is used in much of Europe. The term,

\footnotetext{
${ }^{1}$ I would like to thank the many panelists and discussants who commented on various papers I have drawn from in writing this paper. I would also like to thank Richard W. Slatta for carefully reading an early draft of this paper. The comments of an anonymous reviewer helped me to clarify the logic of my presentation. And finally I thank Jeffery Kentor both for suggesting this paper, and for his patience while I worked on it. As always, remaining errors and problems are mine. The following items all shaped this paper in one way or another: Hall 1989a, 1989b; 1998a, b; 2000a, 2000b, 2000c; 2001a, 2001b; 2002; 2004a, 2004b; 2005a, 2005b, 2005c; 2006a, 2006 b.
} 


\section{PUZZLES IN THE COMPARATIVE STUDY OF FRONTIERS 26}

"borderlands," which refers to a zone on either side of a border or boundary, often is a frontier. Some might argue that transnationalism constitutes a kind of frontier. While that suggestion is not without some merit, the term itself means spanning state boundaries, not the zone of overlap between two states.

The study of frontiers, reviewed briefly later, has often been mired in two problems. The first problem was rooted in garden variety ethnocentrism that conflated the westward moving frontier of the United States with new territories and peoples as it expanded. Ironically, this approach paid little or no attention to frontiers of Spanish expansion. The second problem was a much more serious problem conceptually, theoretically, and historically. All frontiers at first appear to be similar - why the label frontier is applied. However, on much closer inspection each frontier had many specific and peculiar qualities to the appoint that each appears unique.

This, of course, is a classic methodological problem: how to abstract to underlying factors and processes from the messy and fuzzy qualities of social experience and history. Several decades ago Arthur Stinchcombe (1978) noted that a key problem in historical sociology was to figure out what constituted a case or instance of a social factor or process that a researcher wanted to study. Indeed, he offered a caution in the days of rampant quantification, that counting was the last part of the study, not the first.

World-systems analysis, especially comparative world-systems analysis, points to solutions to these problems. This might seem obvious since nearly every frontier (broad generalizations about frontiers are notoriously hard to sustain) is to some extent shaped by processes of interactions among societies - the quintessential subject of world-systems analysis. Indeed, what was missing was a larger framework within which to place both comparative studies and individual case histories. Since all world-systems expand and incorporate new territories and new peoples, they create, transform, and destroy frontiers. Thus, it is a valuable form of analysis to study frontiers. Furthermore, world-system analysis, when done well studies such interactions from the bottom up as well as from the top down. But the world-systems analysis must be used dialectically. Extant world-systems analyses can be a source of theoretical, empirical, and methodological techniques. Conversely, frontier studies can highlight nuances and particularities within general patterns. The use of world-systems analysis also affords opportunities to connect the local and the global in new ways and focus on human agency in world-systemic process.

So why is this suggestion relatively novel? On the one hand, the conflation of frontier in the abstract with westward expansion of the United States from its eastern coast is rooted in the popular imagination, which in the United States (and in many other places) derives from Frederick Jackson Turner's "frontier thesis" (Slatta 1997, 2001, 2003, 2007; Taylor 1972). Jackson argued that the frontier experience in the United States shaped the character of U.S. culture.

Since the late 1980s there has been a near cottage industry among historians of the American West arguing that Turner was wrong, and indeed got it backwards (e.g. Limerick 1987; Limerick et al. 1991). Some of the "new western historians" went so far as to argue for abandoning the term 'frontier' altogether. In part, this is because so many accounts were marked by a triumphalism of the westward march of white males and nearly complete lack of attention to Indigenous peoples, women, and in many cases the environment. Within a few years, however, the F-word was rehabilitated by many of those same historians (Klein 1996; Weber 1986).

Gradually these historians came to see frontiers in a broader context, of which the U.S. frontier was not the archetype (Slatta 2003, 2007; Weber 1986). These new approaches revived a 


\section{JOURNAL OF WORLD-SYSTEMS RESEARCH}

weakened tradition of comparative frontiers (Gerhard 1959; Hofstadter and Lipset 1968; Lamar and Thompson 1981; Lattimore 1951, 1962c). While insightful many of the comparative studies wreaked of the garden variety "compare and contrast" approach, which lends itself to perpetuating the "this example is unique" approach the study of frontiers.

This is where and how world-systems analysis can be very useful. In what follows I will not follow a common format of: here is a list of problems followed by another list of how worldsystems analysis solves those problems. Despite significant work on frontiers and incorporation of new peoples and/or territories into world-systems (e.g. Chase-Dunn and Hall 1997; Hall 2002, 2006a, 2006b), there are too few studies to make such as list. Rather, I seek to contribute to and promote a dialogic discussion of how the study of frontiers and the study of world-systems can usefully inform each other. My goal is not to provide a methodological manual, but to describe some enticing issues and problems upon which such a dialog might be based.

\section{METHODS OF STUDYING FRONTIERS COMPARATIVELY: AN OVERVIEW}

Some of the points I will raise here are rather pedestrian and familiar, others are far less so. I begin by revisiting what constitutes a frontier.

Frontiers are zones or regions that have moved and changed through space with time. Richard W. Slatta $(1997,1998)$ put forth one of the best metaphors for frontiers, that they are membranes. From basic biology we know that membranes have thickness. They only look like lines when viewed from a distance. They are permeable, but that permeability varies both with respect to direction and with respect to what kinds of things may pass through them, and at what rates they pass through them. Membranes have flexibility, the move and stretch in response to various pressures. A similar point was made by Edward Luttwak (1976) in The Grand Strategy of the Roman Empire, where he focuses on walls, such as Hadrian's Wall which supposedly demarcated the northern end of Roman occupation of England. He noted that Hadrian's Wall was far from a complete barrier. In practice it served as a regulator and concentrator of people and goods that passed through it. Other writers (e.g. Lattimore 1951, 1962a, 1962b, 1962c; Barfield 1989) have made similar points about the Great Wall(s) of China (the so-called Great Wall is actually a series of Walls constructed over centuries). The key point here is that walls, such as the Great Wall of China and Hadrian's Wall were really filters, not barriers. As often as not they served as much to keep "civilization" in as to keep "barbarians" out! And, they notoriously failed at both!

There is a large collection of literature that studies frontiers comparatively. This literature is rooted in many disciplines. ${ }^{2}$ One theme that appears repeatedly in comparative studies of

\footnotetext{
${ }^{2}$ The literature on comparative frontiers is actually quite large. I list a few major items here. An excellent resource is Richard W. Slatta's Comparing Frontiers: A Working Bibliography, on line at: http://social.chass.ncsu.edu/slatta/. Many others are also cited in Hall 2001b. Classic sources include: Gerhard 1959; Hofstadter and Lipset 1968; Lamar and Thompson 1981; Lattimore 1940, 1962a, 1962b, 1962c; McNeill 1964; Taylor 1972. Many archaeologists have studied frontiers, some of them comparatively: Godsen 2004; Parker and Rodseth 2005; Smith and Rubinson 2003; Weber and Rausch 1994. There are a number of interesting accounts: Bartlett and McKay 1989;
} 
frontiers is how frontiers that initially seem similar, turn out on closer inspection to be radically different. This "puzzle," why all frontiers seem similar at first glance but then seem unique, demands an account of what social processes could be driving this. This was a common conclusion among a number of scholars, some of whom had reached that point independently.

One "explanation" for this situation is to posit a small number of factors or variables, each divided into a small number of categories. This will generate a large number of types of frontiers. This illustration draws from various studies of frontiers and from world-systems analysis:

- the type of frontier (4 types: buffer, barrier, internal, or external);

- the type of ecological differences (4 types: steppe, sown, hill, or valley);

- the types of nonstate groups (3 types, such as those conventionally labeled bands, tribes, or chiefdoms);

- the types of groups that come into interaction (4 types: non-state, tributary states, tributary empires, capitalist states [Chase-Dunn and Hall 1997]); and

- the type of boundaries involved (4 types: local economic, political or military, longdistance economic, and cultural [Chase-Dunn and Hall 1997]).

These few factors, divided into a few basic categories will generate 768 different types of frontiers (Hall 2001a, 2005a). The list could contain fewer or more factors. They could be divided differently. This would yield a different total of types. For purposes of this argument, it is not necessary to have an exhaustive list of factors, nor an elaborate rationale for the subcategories. Rather, the point is just a few 'variables' with just a few 'categories' can generate a large number of types of frontiers. Indeed, the number of categories itself is not the issue, only that it is sufficiently large that techniques (such as Ragin's [1987] work on Boolean logic) would require an inordinate number of cases to sort out all the variables. Even if this could be done, at this stage it would be premature. Without a sense of what all the factors or variables are it is not possible to construct a list because we have almost no idea of the size of the 'universe' of frontiers. Here we may draw some lessons from basic sampling procedures.

\section{Frontiers and Sampling}

Basic methods and sampling theory show that biased samples, that is samples that over- or underrepresent some aspect of the distribution of the phenomenon one is studying, lead to erroneous conclusions. Recall three old chestnuts of failures of sampling. First is the prediction that Dewey won the election when Truman did, because pollsters did not take into account that Republicans more commonly owned phones than did Democrats. Second, if a random sample is drawn on the basis of the first letter of surnames, the Latino/a population will be over- or under-sampled because a high proportion of Latino/a names begin with the letter "S." Third, there is old story of the spurious correlation of storks and babies. The explanation is of course that in rural areas in Europe storks nest in rural areas (see Figure 1), and rural areas typically have higher birth rates than urban areas.

Figure 1: Stork Nesting on Chimney in Rural Central Poland; June 4, 2004

Chappell 1993; Power and Standen 1999. A few accounts draw heavily on world-systems analysis: Batten 2003; Dunaway 1996. 


\section{JOURNAL OF WORLD-SYSTEMS RESEARCH}

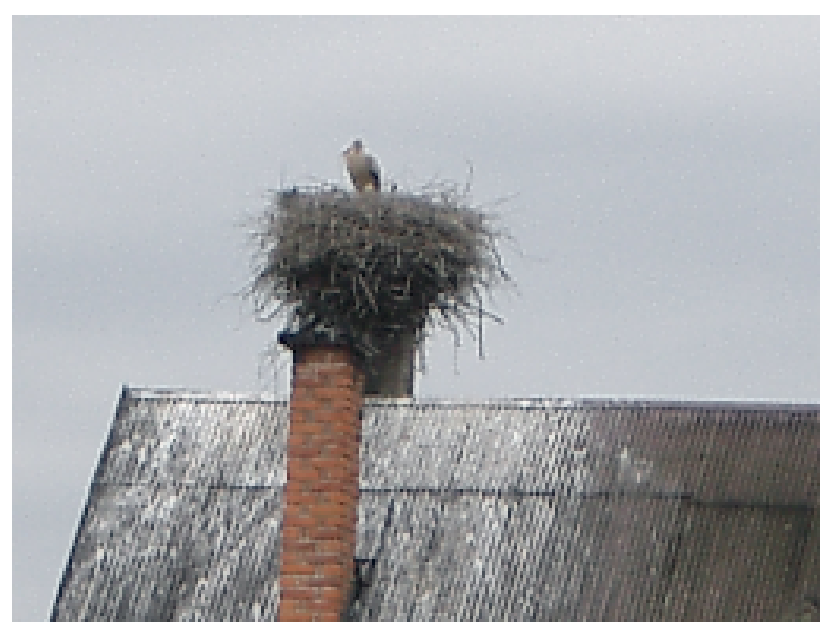

(picture by Thomas D. Hall)

These sorts of problems, combined with a poorly delineated universe, suggest that frontiers need to be studied globally and across time. It is well known that states have changed over time, whether one follows an expanded world-systems view (Chase-Dunn and Hall 1997), or a Frankian world system view (Frank and Gills 1993), or more conventional explanations (Sanderson 1999; Sanderson and Alderson 2005). Thus, to study frontiers sampled from only one type, or more likely, a small range of types of states, could easily miss important variations and variables. More is at stake here than methodological issues. Virtually all studies of frontiers recognize that frontiers are created, shaped, reshaped, and occasionally closed in the interactions of local, regional, state-wide, and global processes (Hall 2000b). To omit one or more types of states could easily hide or mask important sources of variation. Thus macro, micro, and comparative analyses are essential. Therefore the sample should be drawn from the entire world, and at least since the first state appeared, in Ur, some 5,000 years ago. This, of course, omits nonstate - state frontiers (e.g. Hall 1989a) and non-state vs. non-state frontiers (e.g. Chase-Dunn and Mann 1998; Burch 2005). Omitting these latter types could prove to be misleading. Thus, sampling over only one of the three types of societies: state vs. state; state vs. non-state; or nonstate vs. non-state should be done cautiously. Any conclusions should be taken as provisional in light of such limitations.

Even within such limitations, I argue that any 'sampling' of frontiers should pursue a variance-maximizing strategy. Simply put, comparing as widely different types of frontiers as can readily be identified. Again, with eye toward noting any types of frontiers inadvertently omitted. The same argument can be applied to studying peripheral and semiperipheral areas within any world-system. Studies of the modern world-system have been plagued the paucity of reliable data over long periods of time (e.g., centuries).

A common critique of variance maximizing strategies - most common when they are not fully explained - is that one is comparing apples and oranges. But to be a bit waggish about it, apples and oranges are fruit, edible, spherical in shape to name a few similarities. The key point here is legitimacy of a comparison is not found in the objects or institutions being compared, but the theoretical point of the comparison. But that, in turn, implies that the point(s) of the 
comparison are clear. The other source of this objection is an implicit or sometimes explicit rejection of the theoretical agenda for the comparison.

So far I have mentioned "types" of frontiers several times. Earlier I argued that "it is not necessary to have an exhaustive list of factors, nor and elaborate rationale for the subcategories." Here I want to underscore a commonly misunderstood aspect of defining categories, types, subcategories, and often in identifying variables. Basically typologies are heuristic tools for sorting large numbers of instances into groups that, in general, are more similar to each other and that differ in some important way from those in other categories according to one or more identifiable criteria. So again, the categories are theoretically driven, intellectually constructed, and have no agency of their own. A different theoretical agenda suggests rethinking, and often reorganizing the typology. In the opening example if different variables are identified, or if different numbers of subcategories are differentiated, the total number of types of frontiers will change.

Sometimes, as initially discovered by Snyder and Kick (1979), categories such as core, periphery, and semiperiphery have an underlying empirical reality. I argue that there is an analogous situation with respect to frontiers. At this point in time, however, the universe of frontiers is so poorly known that this can not be demonstrated empirically. Still, a reasonable working hypothesis is that there may be an underlying empirical reality that can be useful in guiding and structuring comparisons. As the relevant criteria and measures or indicators of them are developed it would be at least in principle possible to construct elaborate Boolean comparative strategies (Ragin 1987), something along the lines of what John Foran (2005) did in his comparison of Third World revolutions. Another major factor, alluded to in the brief discussion of types of states, is the need to keep track of contexts and scales.

\section{Contexts}

By contexts I am thinking specifically of world-system contexts. These contexts might include the following (e.g., Chase-Dunn and Babones 2006; Chase-Dunn and Hall 1997; Hall 2000c, 2002):

- condition of the world-system: expanding or contracting

- position in the world-system: core vs. semiperiphery vs. periphery

- dynamic: rising or falling or stable

- cyclical position:

$\circ \quad$ a- or b- phase in Kondratieff cycles [about 50 years]

$\circ$ rising or falling in hegemonic cycles [about 100 years]

- rising or falling "long waves" [about 200 years]

○ rising or falling Ibn Kaldhun cycles [about 300 years](Turchin and Hall 2003; Hall \& Turchin 2007);

○ dark age cycles [about 600 years] (Chew 2001, 2007)

The evidence for some of these cycles is quite solid, for others it is quite weak. Few if any of them can reasonably be extended far back in time, though Frank (1993) has argued for K-waves from the Bronze Age forward. The point with regards to comparative strategies is, that if one is unaware of cyclical processes, one can draw quite seriously flawed conclusions (see Figure 2).

\section{Figure 2: Secular Trend with Cycles: Possible Comparisons}




\section{JOURNAL OF WORLD-SYSTEMS RESEARCH}

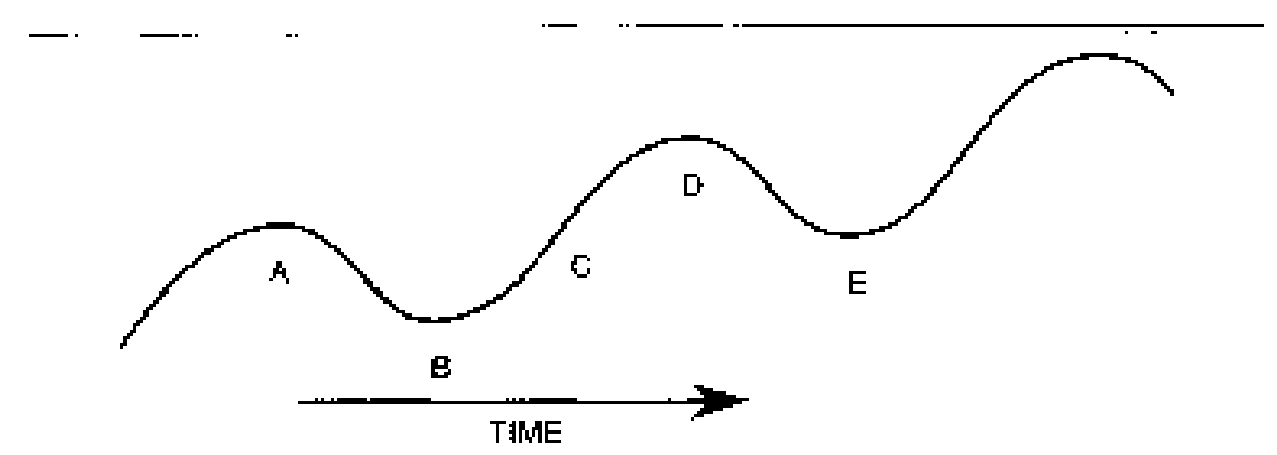

(From Hall 1989:233, based on Skinner 1985:289)

Figure 2 presents a variety of comparison points in a cyclical process which is itself part of a secular trend. Only the comparisons B $-\mathrm{E}$ or A $-\mathrm{D}$ will reveal the underlying secular trend. Comparisons $\mathrm{A}-\mathrm{B}$ or $\mathrm{D}-\mathrm{E}$ would suggest a falling secular trend. If the secular trend were removed, these would be B-phases of a K-wave (Goldstein 1988; Grimes 2000). Comparisons B $-\mathrm{C}, \mathrm{C}-\mathrm{D}$, or $\mathrm{B}-\mathrm{C}-\mathrm{D}$ would overstate the secular trend. If the secular trend were removed these would be an A-phase of a K-wave. Finally comparisons A-C, C-E, or A -C - E would indicate a static condition in which no change occurred.

Furthermore, since we do know a great deal about the dynamics of several of the worldsystem cyclical processes and their complex interactions, failure to attend to these differences could lead to erroneous conclusions. Of course the fuzzier or messier the data are, the more difficult it is to take account of such comparisons. Nevertheless it would seem to be a reasonable working hypothesis that state - state, and even state - non-state frontier interactions would follow somewhat different patterns during an A-phase than in a B-phase, or especially between phases of expansion phases versus phases of contraction. For instance, Thomas Barfield (1989) has demonstrated that, contrary to popular belief, confederations of steppe pastoralists only grew and became strong when China was united and strong. The evidence and argument is complex, but a key point is that raiding and/or trading pastoralists cannot extract wealth from a failing empire.

Cyclical processes are not the only contexts that are relevant. If we conceive of several different types of world-systems, marked by different modes of accumulation, say kin-based, tributary, and capitalist (Chase-Dunn and Hall 1997), we might again expect different sets of frontier dynamics. Failure to consider these possibilities has often led students of the modern world-system to attribute various processes to capitalism, that in fact are actually part of all state systems, such as varieties of ethnic interactions (discussed further below [also see Hall 1998a, 2000b; Chase-Dunn and Hall 1997]). Then there are scale considerations.

\section{Scales}

Scale effects can be both spatial and temporal. The latter are somewhat easier to discuss. If a comparison is made over relatively short periods of time, some sorts of cyclical effects and mode of accumulation effects might be considered static or nearly so. But when comparisons bridge larger time segments these changes cannot be ignored. This, of course, is an issue first raised by 
Braudel $(1979,1980)$ and discussed by John Hall (1980). The consideration of the various worldsystem cycles further suggests there are relevant time scales corresponding to the length of each of the cycles.

There can be analogous spatial scale effects. John Bodley (2003) discusses these in some considerable detail. For instance, once living groups expand beyond a certain population size, on an order of magnitude of 1,000 , it was no longer possible to base all interactions on personal interactions. Bodley argues that this is a factor in the emergence of hierarchy and inequality. Robert Carneiro $(1970,1988,2000)$ argued that circumscription was a major process in the emergence of hierarchy and the origins of the state. These two are not so much opposed, as complementary. The larger the area circumscribed by various barriers the longer and more complex will be the emergence of states and hierarchy.

David Anderson (1994, 1996; see too Hall 2001a) describes in detail how chiefdoms cycle from one to three levels of hierarchy. His argument does not differ radically from Bodley's. Anderson does add an issue of chiefly succession mechanisms as a factor in a collapse from three levels to one, and gradual demographic growth as a factor in movement from one to three levels of hierarchy. Analogous processes can occur among states, empires, and world-systems. It appears that the larger the spatial extent, the longer the temporal cycles, but such a correspondence is far from perfect.

The point here is not to argue the specifics of each of these approaches. Rather, the point is to underscore that issues of scale also play a role in comparative strategies. In general, the shorter the time scale, and the more restricted the spatial scale, the less important changes at the higher levels will be. However, this does not mean they are irrelevant. Rather, for restricted comparisons they may be treated more or less as constants. Still, the value of that constant may be critical in and of itself. This point will be illustrated in the next section where contributions from world-systems analysis for comparative study of frontiers are discussed further.

\section{CONTRIBUTIONS OF WORLD-SYSTEMS ANALYSIS TO COMPARATIVE STUDY OF FRONTIERS}

I begin with a quick sketch of the utility of world-systems analysis for the comparative study of frontiers, highlighting those that are most germane. Chase-Dunn and Hall (1997) show that all world-systems pulsate, that is, expand and contract or expand quickly then slowly. Pulsations are one of many cycles that characterize all types of world-systems. Karl Butzer (1997) pointed out in another context, that the presence of cycles, no matter how crude, is evidence that there is a system.

Chase-Dunn and Hall (1997:275) defined a world-system in the following general terms: "intersocietal networks in which the interactions (trade, warfare, intermarriage, information, etc.) are important for the reproduction of the internal structures of the composite units and importantly affect changes that occur in these local structures." This definition is necessarily abstract to fit all sorts of systems. Note well that this definition leaves as an empirical issue how many "levels" (core, semiperiphery, periphery) a system has, and whether those levels are merely different (core-periphery differentiation) or have some form of hierarchical relationship (coreperiphery hierarchy). They explicitly argue that the transformation of core-periphery 


\section{JOURNAL OF WORLD-SYSTEMS RESEARCH}

differentiation into core-periphery hierarchy remains a thorny empirical and theoretical problem. Of course, none of these issues applies to the modern world-system.

Bounding world-systems is problematic. Chase-Dunn and Hall (1997) argue that worldsystems typically have four sets of boundaries [see Figure 3], marked by sharp falloffs in density of exchange of bulk goods, political and military interactions, luxury or prestige goods exchanges, and information exchanges:

- a bulk goods network (BGN) a system of exchange of low value to weight goods;

- a political-military network (PMN) of regularized military or political interactions;

- a prestige or luxury goods network (PGN) of more or less regular exchange of high value to weight goods; and

- an information or cultural network (IN) of regularized exchanges of information.

The sharp lines in Figure 3 give a false sense of precision. Rather, one should imagine a contour map of the density of exchanges in these networks. The "boundary" of any one network would be a region where there is a very steep fall off in exchange densities. In this sense, they are frontiers internal to a world-system. Exchange must be systemic - even if inchoate - to form a boundary zone. Note, too, that whether a specific good is a bulk or luxury good is only partially a property of the good itself. Whether a good is bulk or luxury is also a consequence of transportation costs, and productive use of the good in both the sending and receiving economies.

\section{Figure 3: Word-System Networks}

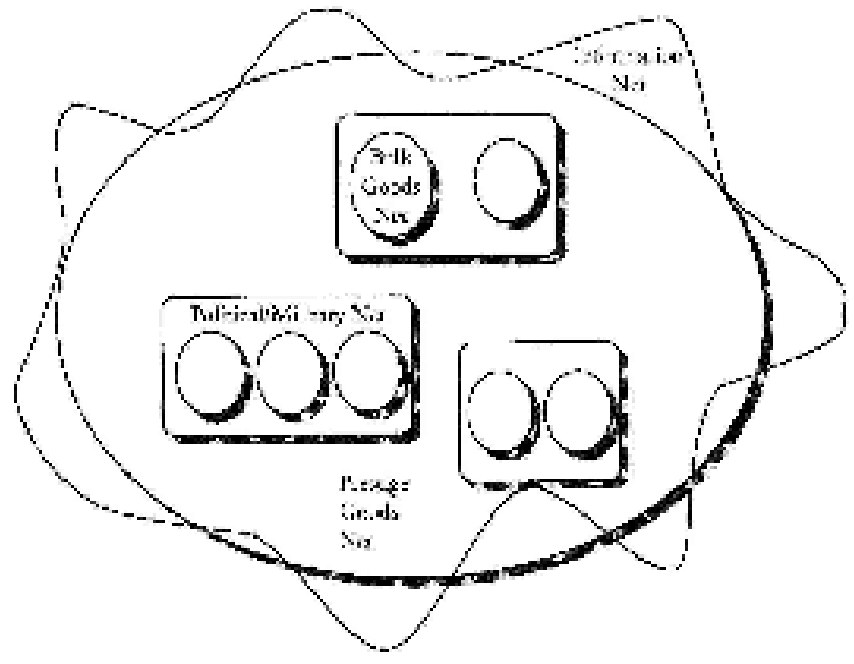

(from Chase-Dunn and Hall 1997:54)

\section{Incorporation into World-Systems}

As noted, one dynamic property of world-systems is that they all pulsate, with a net tendency to increase in size and incorporate new territories and/or peoples (this discussion draws heavily on 
Hall 1987, 1989a, 2006b; Chase-Dunn and Hall 1997; Carlson 2001, 2002; Hollis 2004, 2005). Typically these processes differ for each of the networks.

A world-system typically, but not always, incorporates new territories and/or new peoples as peripheral areas. These zones of incorporation are often called frontiers by others. This approach to incorporation includes the following:

- begins with much less contact than originally conceived;

- its impacts are typically asymmetrical in favor of core regions;

- is reversible only to a limited extent;

- forms a continuum of incorporation, that it has "fuzzy" or vague limits at the weak pole. Figure 4 diagrams this conception and provides a concordance of parallel or analogous terms.

Shirley Hollis $(2004,2005)$ summarizes these arguments and provides additional empirical support for this conceptualization. Jon Carlson $(2001,2002)$ argues that modern incorporation processes are more complex than even this continuum concept implies. Caleb Bush $(2005 \mathrm{a}, \mathrm{b})$ claims that there is no inherent endpoint to incorporation. Rather, it is a continuing part of capitalist deepening processes that shift with shifts in the world-system and localized responses to those shifts. He further argues that incorporation is uneven, more of a fishnet process that has "holes" both temporally and spatially. These emendations probably also apply to pre-capitalist settings.

Figure 4: The Continuum of Incorporation

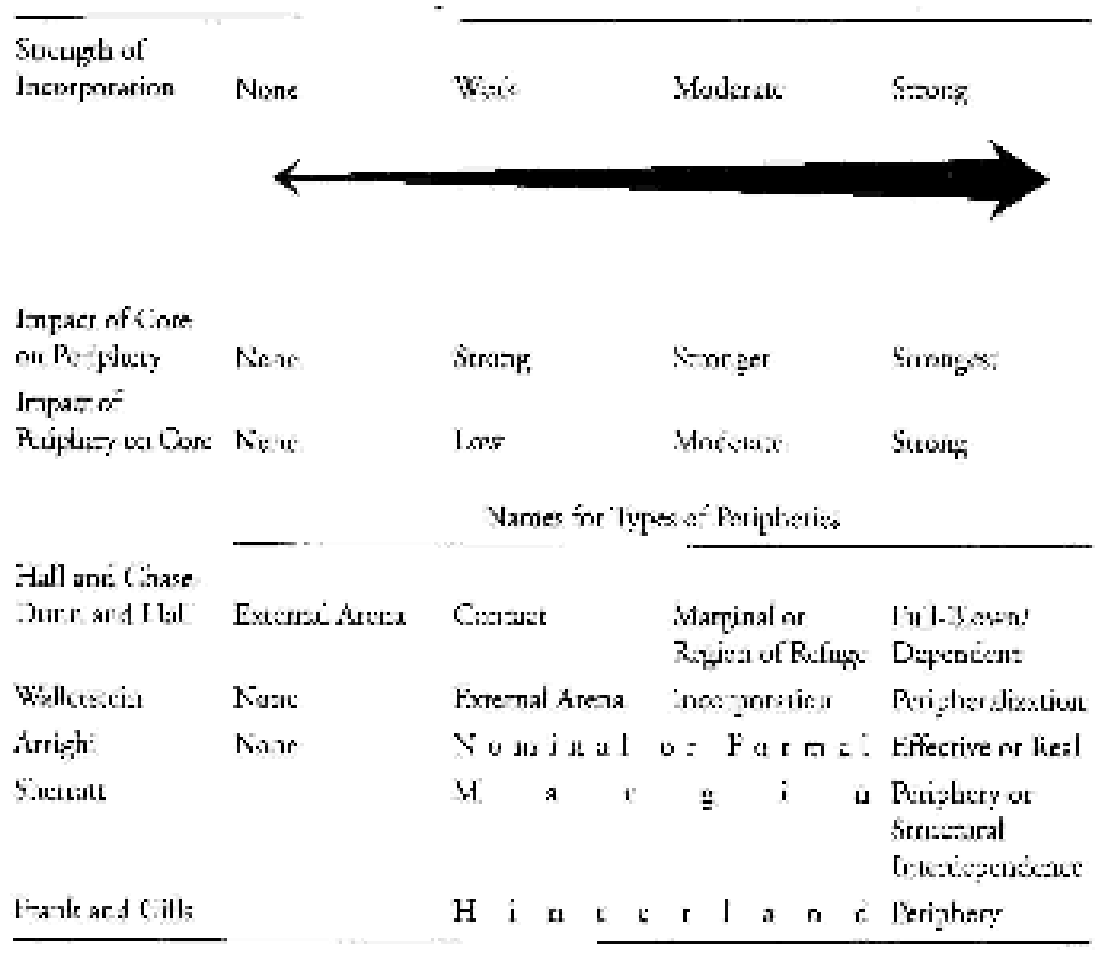

(from Chase-Dunn and Hall 1997:63) 


\section{JOURNAL OF WORLD-SYSTEMS RESEARCH}

If zones of incorporation are, or become frontiers, then clearly a large number of processes can create many different types of frontiers. Furthermore the types, densities, and social processes in those frontier zones have changed with the evolution of world-systems.

Recent work on synchrony among population, city size, and empire size (e.g. ChaseDunn and Hall 1997; Chase-Dunn, Manning and Hall 2000; Chase-Dunn and Manning 2002) shows that even low levels of incorporation can cause various cyclical processes to become synchronized. Similarly, related work based in faunal population ecology models has begun to explain cyclical processes and synchrony among cyclical processes among ancient world-systems (Turchin and Hall 2003; Hall and Turchin 2007; Chase-Dunn, Hall, and Turchin 2007). A major insight from these studies is that it takes relatively low levels of interaction, such as long distance luxury trade, to synchronize various social processes. Such processes may account for what may seem like "action at a distance" among geographically widely separated frontiers. It also suggests one of the world-system mechanisms by which system-level events shape, or serve as a context for, frontier processes.

Finally, these zones of incorporation, or frontiers, are arenas where processes of identity formation, reformation, transformation, and annihilation are both more contested and more visible at several scales simultaneously than is typically the case in core regions. This approach in essence argues that Hill's (1996a, 1996b) critique of world-system analysis with respect to ethnogenesis and ethnocide, is actually an instance of how world-system processes work out in space and time.

It is important to note here that none of these relations can be readily discerned without using a world-system approach. Comparative frontier strategies, which typically compare only a small number of frontiers (less than five, often only two), are insufficient to uncover such processes.

I have emphasized the weaker pole of the continuum of incorporation where boundaries are especially fuzzy. An important point, both methodologically and theoretically, is that this "fuzziness" is not a result of poor measurement or indicators. Rather, it is a reflection of an underlying reality that is fundamentally indeterminate. This suggests that as more knowledge and data are collected fuzzy set analysis (Ragin 2000) may be a useful tool for studying these processes. $^{3}$

My studies of European intrusions into what is now southwestern United States show that even very mild forms of incorporation can have drastic effects on incorporated regions and peoples (see especially Hall 1989a for detailed examples; Hollis 2005 shows similar processes for Southeastern U.S.). Following Sing Chew's work $(2001,2007)$ on ecological degradation, the ecological footprint of an urban area is quite large, extending into a large hinterland, or in the terms used here into regions that are only mildly incorporated. In both these sets of examples the degree of incorporation is only along the prestige goods and/or information networks, and often at

\footnotetext{
${ }^{3}$ Ironically students of globalization who claim that contemporary state boundaries are becoming less important, and that transnational process are becoming more important, are arguing and documenting how formerly relatively sharp boundaries are becoming fuzzy, or vague. For instance, Sklair (2002) and Robinson (2004) provide plausible evidence for the formation of a transnational capitalist class. The formation of such a transnational class is rendering borders less important and vaguer. This is a process that seems to be the inverse of world-system expansion and incorporation. It merits further theorizing, but is beyond the intent of this paper.
} 
a low level. Still the effects on local areas can be profound. An effect R. Brian Ferguson and Neil Whitehead (1992a, 1992b), Jonathan D. Hill (1996a), and Ken Coates (2004) have also noted (though these writers do not use the term incorporation nor do they use world-systems analysis).

These world-system processes are a major source of the puzzle of frontiers -- that they all seem similar, but upon closer examination, each frontier seems unique (Hall 2001b, but see also Lamont and Molnár 2002; Lightfoot and Martinez 1995; Rice 1998; Rice and Rice 2005). Frontiers can also give rise to buffer zones that are emptied of residents, and thus leave room for local ecologies to recover from over use (Martin and Szuter 1999; Rice and Rice 2005). Furthermore, processes that first occur in newly incorporated regions may rebound back to more central areas to produce further changes there. Indeed, this seems to be a part of why semiperipheral marcher states are often instigators of significant system change (see Chase-Dunn and Hall 1997; Hall, Chase-Dunn and Niemeyer forthcoming; Lattimore 1980).

As noted, frontiers are zones of ethnic change: formation, transformation, amalgamation, fractionation, or destruction. Destruction of an ethnic group does not necessarily require death of members of the group, it can also be due to destruction of the identity (ethnicide, or for some, assimilation) or destruction of a culture (culturicide). In such processes all levels of context interact. This can be very difficult to disentangle.

In Captives \& Cousins, James Brooks (2002) chastises me for being far too structural. He is voicing a common criticism of any structural analysis: actors are left out, it is too abstract. It is a criticism with some merit, but only SOME. It calls to mind a comment by Robert Pirsig (1974:26) about how two of his motorcycling companions could not be bothered with the technology of motorcycle maintenance: "The Buddha, the Godhead, resides quite as comfortably in the circuits of a digital computer or the gears of a cycle transmission as he does at the top of a mountain or in the petals of a flower."

Analogously, what happens as local history is still part of a world-system, and plays an important role in its overall dynamics and evolution, and is a vital part of the system's history. Furthermore frontiers, with their great messiness and myriad anomalies, are great places to "seize the Buddha," to see how local processes connect to global and long-term processes.

Yet, of the things Brooks does very well - and he does many things well - is to show the complexity of ethnic and racial interactions along the Southwestern frontiers, note the S. But he then leaps to the erroneous conclusion that race and ethnicity are not key structural factors. This is similar to Janet LeCompte's (1985) claim that the revolts in northern New Mexico in 1836 in Chimayo, then again in 1847, wherein new American governor Charles Bent had his spine relieved of the burden of supporting his head, had nothing to do with race or class. Andrés Reséndez (2005) gently notes that the major players in both rebellions were Pueblo Indians. Nope, race was not an imporant factor!

Both Brooks and Lecompte missed the Buddha. Maybe they only took intro to Sociology wherein all too often race, class, and gender are painted with far too broad of a brush. I do not think that this is the case. Rather, to go back to Pirsig, they did not see the Buddha because they were not looking for him. In less metaphorical terms, structural processes, world-systemic, ethnic, and so on operate in interaction with other processes, especially local processes and individual agency in complex ways. This is well illustrated in Ned Blackhawk's (2006) Violence over the Land which carefully details such interactions and their multifaceted consequences for and resistance to larger processes that disrupted Paiute social life from the eighteenth through the twentieth centuries. 


\section{JOURNAL OF WORLD-SYSTEMS RESEARCH}

What a world-system approach contributes to all of these studies are explanations of why these supposed individually motivated processes (a.k.a. agency) occur where they did (on frontiers) and when they did (when the cyclical condition of state strength was insufficient to regulate such interactions). Put another way, world-system analysis explains how the structural conditions originate that allow individual agency to have such force locally.

This underscores another methodological (and theoretical) contribution of world-systems analysis to the study of frontiers. Frontiers, peripheries, and other "obscure" places offer many opportunities to observe and understand the interactions among local, regional, state-level, systemic, and since the late twentieth century global processes. Indeed, occasionally they are the only place where these interactions can be studied because core, and even semiperipheral process are so strong that these more subtle interactions are all but invisible (Hall 1989b). In short, frontiers are great places to seize the Buddha: to draw the connection between global, longue duree and the most micro of interactions. This is where empirical studies of frontiers can contribute to refined world-system theorizing. Conversely, this is where world-systemic processes can account for contexts which promote or inhibit levels of individual agency.

I illustrate some of these interactions in a brief discussion of nationalism and identity on frontiers.

\section{IDENTITIES, ETHNICITIES, RACES, AND NATIONALISMS ON FRONTIERS}

Frederik Barth (1969) in Ethnic Groups and Boundaries claimed: "The critical focus of investigation from this point of view becomes the ethnic boundary that defines the group, not the cultural stuff that it encloses." Barth's key argument is that such boundaries often coincide with ecological boundaries, where, given a fixed technology, the mode of making a living must change at the boundary. This is a key element in such differences as between the steppe and sown, between hills and valleys, and so on. It also stands on its head an all too common approach that says that ethnic differences create boundaries and frontiers.

Frontiers are where identities crash, conflict, coalesce, and become conflated. Frontiers are ideal places to study how identities are born, shaped, reshaped, and destroyed. Yet they are also full of contradictions, dissembling, confusions, and murky processes. Hence they are fascinating and frustrating areas to study. But I think social scientists have been wont recently to exaggerate the importance of identities. We too often give them causal primacy, or in basic methods terms, view them only as independent variables, even while we are expounding on how they are socially constructed, which means we are claiming they are dependent variables.

Barth's claim, and my claim which is a bit more forceful, may seem counter intuitive. To a large extent they are. There seems to have been a vast increase in recent decades of ethnic conflict and violence as documented by Gurr $(1993,2000)$ and Harff \& Gurr (2004). Yet Wilma Dunaway (2003) argues, that there has not so much been an increase in ethnic conflict and violence as an increase in its costs to global capitalism. Clearly, identity is vitally important.

My argument here is that identities, as manifest in ethnicity, race, nationalism, and so on are more often consequences, results, or outcomes of social processes than they are causes. To be sure, once they are in place they become part of complex feedback or recursive processes, which when narrowly viewed appear to play causal roles. But in highly recursive systems the concept of cause between variables itself becomes very muddy at best. This is part of Barth's point, too as I 


\section{PUZZLES IN THE COMPARATIVE STUDY OF FRONTIERS 38}

read him and his examples: it is the boundary that maintains the ethnicity, not the reverse. In short, identities are what need to be explained. Before proceeding with this line of argument and connecting it to the study of frontiers, I want to return to a critical comment on Karl Marx (Hall \& Fenelon 2003, 2004).

In Charles Kenner's (1969) History of New Mexican - Plains Indians Relations, James Brooks's Captives and Cousins (2002), and Ned Blackhawk's Violence over the Land (2006) present accounts about how during raids nomadic Indians routinely killed all males at or beyond puberty, but took women, and minor children of either sex, captive or sold them off to Spaniards for slaves, or traded them to redeem their own people who had been captured by Spaniards. These accounts describe how such children were often absorbed into the societies of their captors and grew up to become full-fledged members of the group, at least culturally. Here a parenthetical note that the peoples the Spaniards were accustomed to call los indios bárbaros, did this much more often than Spaniards who typically consigned captives to a degraded ethnic category of genizaro (Hall 2004a; Weber 2005). The surprising lesson is that these captured children grew up to be quite healthy adults, at least within what was considered healthy in their new home societies. In short, their identities changed.

So if identity is "so easily" changed, especially if we consider myriad instances where individuals or groups - here Barth's accounts come to mind - voluntarily shift identities, how can it be more important than class, which in practice is often more difficult to change? Part of the answer is that identity communities are forms of social organization not based capitalist relations. This is not a "primordialist" or "essentialist" claim. Rather, it is a recognition that the fundamental social link in identity groups is one of kinship and community, irrespective of how they make their living. This is where Marx errs. He failed to recognize that ties of common work experiences - relations of production - are often not sufficiently powerful to overcome completely ties of kinship and face-to-face community. This is why both nations and movements always adopt metaphors of kinship to build solidarity; or to invert Benedict Anderson (1991), that is why the "imagined community" must be imagined. It must be socially constructed because it is not there spontaneously (Geary 2002). This is not to gainsay that such a transformation might happen, but rather to note that such transformations are rare. But here Marx deserves some credit on this issue. Although humans construct their own histories, and their own identities, they cannot do so any old way. There are constraints. Figuring out what they are, how they work, and just how constraining they are remains to be done, though many of the new western historians have begun to do so (e.g., Blackhawk 2006; Brooks 2002, Limerick et al. 1991; Reséndez 2005; Robbins 1994; Slatta 1997; Weber 2005). Furthermore, world-systems analysis offers ways to delineate where and when such processes are more, or less, likely. Consideration of the phases of various world-systemic cycles, degree of incorporation into a world-system, and world-system position - core, periphery, semiperiphery - and relative change, rising or falling in world-system position are all important contextual conditions to analyzing the timing and location of many different kinds of ethnic change.

Indeed, identity groups, such as ethnic groups, are typically constructed historically. Where the historical depth is sufficient (what is sufficient is itself problematic), it can often appear "natural," "primordial," "essential," or "racial." In those times and places where humans did not move far from their home territories there is in fact a real association of phenotypical features, culture, and identity. This association, however, is not "natural," "normal," or "primordial," but an artifact of relative geographical stability, which itself is historically rooted 


\section{JOURNAL OF WORLD-SYSTEMS RESEARCH}

(for further details see Hall 2004b). If 19th century factory organization had remained stable for many decades or for centuries, class might have become a major identity group. However, identity groups in fact change and transmute through time, fragmenting, amalgamating, and exchanging members. Where these processes are slow, they may appear to be racial or biological because their social and historical construction is not readily perceptible to a casual observer. Where they are faster the social construction is more apparent. Hence, the increased concern with the social construction of identity in recent decades.

It is precisely because such processes are more contested and often change more rapidly in frontier regions that frontiers are good places to study the processes of such changes. In fact in frontier zones it is ethnic or identity persistence, rather than change that is problematic. This is precisely why studies like Brooks's (2002) Captives and Cousins can be insightful. However, Andrés Reséndez's (2005) Changing National Identities at the Frontier or Ned Blackhawk's (2006) Violence over the Land are also useful. These two accounts focus precisely on the interplay of local, regional, state-level, and world-systemic forces in shaping these ethnic processes. In the longer term perspective used here, one could add part of the shaping is because these processes were occurring on the peripheries of nascent capitalist states. Quite often, but not always, tributary states had far less concern with identity and culture, and more concern with minimizing resistance and a facilitating trade and collection of taxes (or tribute).

In short, although the kind of world-system was not changing, or not changing rapidly during the periods of these studies, its position - nascent capitalist states - was an important background 'constant' to other processes of change operating at a much faster time scale.

So what kind of methodological lessons might we draw from these accounts?

\section{CONCLUSION: STRATEGIZING COMPARISONS AMONG FRONTIERS}

Clearly, variations can be spatial, temporal, physiographic, or organizational, different kinds of native peoples, and different sorts of settlers. So these are all factors that must be considered in comparisons. Also important are type, phase, type of boundary, and state of the world-system(s) that are shaping frontiers and that frontiers are influencing. It would also seem reasonable to consider whether the frontier was on the edge of a world-system, whether it be at the bulk goods, political-military, luxury goods, on informational edge or along some internal boundary. Internal boundaries could be between states or groups in similar positions within the world-system (e.g., core, periphery, or semiperiphery) or they could be between these different zones. A reasonable working hypothesis would be that these two broad categories of frontiers would exhibit different dynamics. Blackhawk's (2006) study focuses more on the edge of the system, whereas Reséndez's (2005) study is concerned with the processes of identity change within the system (as what is now southwestern United States was wrested from Mexican control).

A subsidiary hypothesis might be that frontiers between different positions in a worldsystem might also differ. Here it is useful to recall Chase-Dunn and Hall's (1997) claim that how many layers, and how differentiated they are in a world-system is an empirical as well as a theoretical problem.

So how should one make comparisons? One strategy would be to choose frontiers that vary only along a few dimensions. This was largely the strategy in Contested Ground (Guy and Sheridan 1998a, 1998b) which compared the extreme northern and southern edges of the Spanish 
Empire in the Americas. World-system position and dynamics, if not constant, changed in similar ways for most of the empire. This facilitated closer focus on types of indigenous organization, ways of making a living, and various geographical features.

Often, however, one does not have the luxury of having appropriate frontiers to compare. Rather, one must examine the cases at hand to figure out what is different and what is the same, then investigate whether some of those differences are causally, or recursively, connected to other changes. What differentiates this approach from 'garden variety compare and contrast' approaches, is the harnessing of its theoretical concerns with an eye to discovering new variables in frontier processes.

Another strategy, discussed extensively by Richard W. Slatta (1997), is to examine one institution, the cattle ranch, in many different frontier settings. While for the most part nineteenthcentury cattle ranches employed similar technologies for cattle breeding, raising, and controlling, they were often located in different kinds of markets, and connected in the world-economy in different ways. A major factor in the transformation of cattle ranches was the development of reliable refrigeration technology in the late nineteenth century which allowed more extensive and tighter connections between the ranches and their potential markets. These had massive effects on the ranching industry (Slatta 1990).

In Class \& Community Richard Hogan (1990) follows a similar strategy, arguing that the miners and farmers in nineteenth century Colorado developed divergent self-governing styles out the interaction of the specific relations of production with larger society. Given that both mining and farming are primary extractive industries, this is quite interesting. It suggests that "extractive industry" is too inclusive of a category, which has many important variations. As in the Contested Ground (Guy and Sheridan 1998a) project this comparison holds relatively constant position in the world-system, and world-system time. This allows foregrounding the critical role of the relations of production and the roles of individual actors.

Many case studies of frontiers can be [re]interpreted as 'incorporated comparisons' (McMichael 1990) which are often a series of comparisons within an historical trajectory of a case. In Colony and Empire William Robbins (1994) examines the American West and argues that far from being an open or free frontier, it was highly constrained by the demands of assorted capitalist enterprises. This, of course, makes sense within a world-systems framework. But it also sheds a different light on the common claim that in Canada the law arrived before the settlers, whereas in the United States the settlers preceded the law, and hence the western U.S. was far more violent than western Canada. Rather, frontier violence served the interests of capital. Blackhawk (2006) shows that violence served to 'ethnically cleanse' the U.S. west of indigenous peoples. This, in turn can be seen as yet another instance of 'war in the tribal zone' (Feguson and Whitehead 1992a, 1992b; Whitehead 2004a, 2004b). Here it interesting that the 'war in the tribal zone' effect occurs in both tributary and capitalist world-systems. Thus, as with ecological degradations discussed by Chew (2001), a key component of change is the state, irrespective of the mode of accumulation.

In analogous ways comparisons of modern and ancient frontiers show that genocide, ethnocide, culturicide, ethnogenesis, amalgamation, and fractionation are common processes on many different frontiers. What remains to be studied systematically is how various local, regional, state-level, and world-system conditions and dynamics shape these processes. Again, states seem to be as important as mode of accumulation and local relations of production in shaping ethnic change. 


\section{JOURNAL OF WORLD-SYSTEMS RESEARCH}

This entire discussion can be useful in the study of other kinds of social structures and processes. That is, these world-system considerations in strategically making comparisons potentially have very broad applications. However, they need to be adapted to specific theoretical and empirical concerns. In particular, it is in these kinds of studies that one of the common critiques of world-systems analysis can be answered: that it ignores local actors and/or noneconomic processes.

Finally, the study of frontiers illustrates how much can be learned by the study of peripheral regions and peoples and their roles in system change (Chase-Dunn and Hall 1997, Ch. 5; Hall 1989b; Lattimore 1980; Hall and Fenelon 2009). Indeed, some of these processes may be visible only in peripheral and/or frontier areas. This then becomes a method to explore how it is that actions and changes in peripheral areas (and semiperipheral areas) play important roles in world-system evolution. A key point here is that many if not most of these questions can only be asked from a world-system perspective, even if they must be answered in large part locally.

\section{REFERENCES}

Anderson, Benedict. 1991. Imagined Communities: Reflections on the Origin and Spread of Nationalism. London: Verso.

Anderson, David. G. 1994. The Savannah River Chiefdoms: Political Change in the Late Prehistoric Southeast. Tuscaloosa: University of Alabama Press.

. 1996. "Fluctuations Between Simple and Complex Chiefdoms: Cycling in the Late Prehistoric Southwest." Pp. 231-252 in Political Structures and Change in the Prehistoric Southeastern United States, edited by J. F. Scarry. Gainesville, FL: University Press of Florida.

Barfield, Thomas J. 1989. The Perilous Frontier. London: Blackwell.

Barth, Frederik. 1969. Ethnic Groups and Boundaries. Boston: Little Brown.

Bartlett, Robert and McKay, Angus, eds. 1989. Medieval Frontier Societies. Oxford: Oxford University Press.

Batten, Bruce L. 2003. To the Ends of Japan: Premodern Frontiers, Boundaries, and Interactions. Honolulu: University of Hawaii Press.

Blackhawk, Ned. 2006. Violence over the Land: Indians and Empires in the Early American West. Cambridge, MA: Harvard University Press.

Bodley, John H. 2003. Power of Scale: A Global History Approach. Armonk, NY: ME Sharpe.

Braudel, Fernand. 1979. Afterthoughts on Material Civilization and Capitalism. Translated by Patricia Ranum. Baltimore: Johns Hopkins University Press. . 1980. "History and the Social Sciences: The Longue Duree." Pp. 25-54 in F. Braudel (ed., Tr. Sarah Matthews), On History. Chicago: University of Chicago Press [Orig. 1958 in Annales E.S.C., 4 (Oct.-Dec.): 725-753].

Brooks, James F. 2002. Captives and Cousins: Slavery, Kinship, and Community in the Southwest Borderlands. Chapel Hill: University of North Carolina Press.

Burch, Ernest S., Jr. 2005. Alliance and Conflict: A World System of the Iñupiaq Eskimos. Lincoln: University of Nebraska Press. 
Bush, Caleb. 2005a. "Land, Conflict, and the 'Net of Incorporation': Capitalism's Uneven Expansion into the Navajo Indian Reservation 1860-2000." PhD. Dissertation, Binghamton University, Department of Sociology.

. 2005b. "Reconsidering Incorporation: Uneven Histories of Capitalist Expansion and Encroachment, Native America." Studies in Political Economy 76:83-109.

Butzer, Karl W. 1997. "Sociopolitical Discontinuity in the Near East C. 2200 BCE: Scenarios from Palestine and Egypt." Pp. 245-296 in Third Millennium BC Climate Change and Old World Collapse, edited by H. Nuzhet Dalfes, George Kulka, and Harvey Wiess. Berlin: Springer Press.

Carlson, Jon D. 2001. Broadening and Deepening: Systemic Expansion, Incorporation and the Zone of Ignorance. Journal of World-Systems Research 7(2):225-263.

Carlson, Jon D. 2002. "The 'Otter-Man' Empires: The Pacific Fur Trade, Incorporation and the Zone of Ignorance." Journal of World-Systems Research 8(3):389-442.

Carneiro, Robert L. 1970. "A Theory of the Origin of the State." Science 169:733-38. . 1988. "The Circumscription Theory: Challenge and Response." American Behavioral Scientist 31:497-511.

. 2000. The Muse of History and the Science of Culture. New York: Kluwer Academic/Plenum Publishers.

Chappell, David A. 1993. "Ethnogenesis and Frontiers." Journal of World History 4(2):267-275

Chase-Dunn, Christopher and Salvatore J. Babones. 2006. Global Social Change: Comparative and Historical Perspectives. Baltimore: Johns Hopkins University Press.

Chase-Dunn, Christopher and Thomas D. Hall. 1997. Rise and Demise: Comparing WorldSystems. Boulder: Westview Press.

Christopher Chase-Dunn, Thomas Hall, \& Peter Turchin. 2007. "World-Systems in the Biogeosphere: Urbanization, State Formation, and Climate Change Since the Iron Age." Pp.132-148 in The World System and the Earth System: Global Socioenvironmental Change and Sustainability Since the Neolithic, edited by Alf Hornborg and Carole L. Crumley. Walnut Creek, CA: Left Coast Books.

Chase-Dunn, Christopher and Kelly M. Mann. 1998. The Wintu and Their Neighbors: A Very Small World-System in Northern California. Tucson: University of Arizona Press.

Chase-Dunn, Christopher and E. Susan Manning. 2002. "City Systems and World-Systems: Four Millennia of City Growth an Decline." Cross-Cultural Research 36(4):379-398.

Chase-Dunn, Christopher, Susan Manning, and Thomas D. Hall. 2000. "Rise and Fall: East-West Synchronicity and Indic Exceptionalism Reexamined." Social Science History 24(4):727754.

Chew, Sing C. 2001. World Ecological Degradation: Accumulation, Urbanization, and Deforestation 3000 B.C. - A. D. 2000. Walnut Creek, CA: Altamira Press.

. 2007. The Recurring Dark Ages: Ecological Stress, Climate Changes, and System Transformation. Lanham, MD: Altamira Press.

Coates, Ken S. 2004. A Global History of Indigenous Peoples: Struggle and Survival. New York: Palgrave.

Dunaway, Wilma A. 1996. The First American Frontier: Transition to Capitalism in Southern Appalachia, 1700-1860. Chapel Hill: University of North Carolina Press.

. 2003. "Ethnic Conflict in the Modern World-System: The Dialectics of Counter-hegemonic Resistance in an Age of Transition." Journal of World-Systems Research 9(1):3-34. 


\section{JOURNAL OF WORLD-SYSTEMS RESEARCH}

Ferguson, R. Brian, and Neil L. Whitehead, eds. 1992a. War in the Tribal Zone: Expanding States and Indigenous Warfare. Santa Fe, NM: School of American Research Press.

. 1992b. "The Violent Edge of Empire. Pp. 1-30 in R. B. Ferguson and N. L. Whitehead, eds. War in the Tribal Zone. Santa Fe, New Mexico: School of American Research Press.

Foran, John. 2005. Taking Power: On the Origins of Third World Revolutions. Cambridge: Cambridge University Press.

Frank, Andre Gunder. 1993. "The Bronze Age World System and its Cycles." Current Anthropology 34(4):383-413.

Frank, Andre Gunder and Barry K. Gills, eds. 1993. The World System: Five Hundred Years or Five Thousand? London: Routledge.

Geary, Patrick J. 2002. The Myth of Nations: The Medieval Origins of Europe. Princeton: Princeton University Press.

Gerhard, Dietrich. 1959. "The Frontier in Comparative View." Comparative Studies in Society and History 1(3):205-229.

Gosden, Chris. 2004. Archaeology and Colonialism: Culture Contact from 5000 BC to the Present. Cambridge: Cambridge University Press.

Goldstein, Joshua. 1988. Long Cycles: Prosperity and War in the Modern Age. New Haven: Yale University Press.

Grimes, Peter. 2000. "Recent Research on World-Systems." Pp. 29-55 in A World-Systems Reader: New Perspectives on Gender, Urbanism, Cultures, Indigenous Peoples, and Ecology, edited by Thomas D. Hall. Lanham, MD: Rowman \& Littlefield.

Gurr, Ted Robert. 1993. Minorities at Risk: A Global View of Ethnopolitical Conflicts. Washington, D.C.: United States Institute for Peace Press.

, ed. 2000. Peoples versus States: Minorities at Risk in the New Century. Washington, D.C.: United States Institute of Peace Press.

Guy, Donna J. and Thomas E. Sheridan, eds. 1998. Contested Ground: Comparative Frontiers on the Northern and Southern Edges of the Spanish Empire. Tucson: University of Arizona Press.

. 1998b. "On Frontiers: The Northern and Southern Edges of the Spanish Empire in America." Pp. 150-166 in Contested Ground: Comparative Frontiers on the Northern and Southern Edges of the Spanish Empire, edited by Donna Guy and Thomas Sheridan, University of Arizona Press.

Hall, John R. 1980. "The Times of History and the History of Times." History and Theory 19:113-131.

Hall, Thomas D. 1987. "Native Americans and Incorporation: Patterns and Problems." American Indian Culture and Research Journal 11(2):1-30.

. 1989a. Social Change in the Southwest, 1350-1880. Lawrence, KS: University Press of Kansas.

. 1989b. "Is Historical Sociology of Peripheral Regions Peripheral?" Pp. 349-372 in Studies of Development and Change in the Modern World, edited by Michael T. Martin and Terry R. Kandal. Oxford: Oxford University Press.

. 1989c. "Historical Sociology and Native Americans: Methodological Problems." American Indian Quarterly 13(3):223-238. 
. 1998a. "The Effects of Incorporation into World-Systems on Ethnic Processes: Lessons from the Ancient World for the Contemporary World." International Political Science Review 19(3):251-267.

. 1998b. "The Rio de La Plata and the Greater Southwest: A View From World-System Theory." Pp. 150-166 in Contested Ground: Comparative Frontiers on the Northern and Southern Edges of the Spanish Empire, edited by Donna Guy and Thomas Sheridan. Tucson, AZ: University of Arizona Press.

, ed. 2000a. A World-Systems Reader: New Perspectives on Gender, Urbanism, Cultures, Indigenous Peoples, and Ecology. Lanham, MD: Rowman \& Littlefield Press.

. 2000b. "Frontiers, Ethnogenesis, and World-Systems: Rethinking the Theories." Pp. 237270 in A World-Systems Reader: New Perspectives on Gender, Urbanism, Cultures, Indigenous Peoples, and Ecology edited by Thomas D. Hall. Lanham, MD: Rowman \& Littlefield.

. 2000c. "A Heuristic for Comparing Frontiers," for panel on Comparative History and the Americas. Paper presented at the Western History Association, San Antonio, TX, Oct. 11-14.

. 2001a. "Chiefdoms, States, Cycling, and World-Systems Evolution: A Review Essay." Journal of World-Systems Research 7(1):91-100.

. 2001b. "Using Comparative Frontiers to Explore World-Systems Analysis and International Relations." International Studies Perspectives 2(3): 253-269.

. 2002. "World-Systems Analysis and Globalization: Directions for the Twenty-First Century." Pp. 81-122 in Theoretical Directions in Political Sociology for the 21st Century, Research in Political Sociology, Vol. 11, edited by Betty A. Dobratz, Timothy Buzzell, Lisa K. Waldner. Oxford: Elsevier Science Ltd.

. 2004a. "Genizaros. P. 356 in Encyclopedia of the Great Plains, edited by David Wishart. Lincoln: University of Nebraska Press.

. 2004b. "Ethnic Conflict as a Global Social Problem." Pp. 139-155 in Handbook of Social Problems: A Comparative International Perspective, edited by George Ritzer. Thousand Oaks, CA: Sage Publications.

. 2005a. "Borders, Borderland, and Frontiers, Global." Pp 238-242 in New Dictionary of the History of Ideas, Vol. 1 edited by Maryanne Cline Horowitz. Detroit: Charles Scribner's Sons.

. 2005b. "Frontiers as Zones of Interaction: Finding the Buddha in the Shard Pile." Paper Presented at American Society for Ethnohistory Meeting, Santa Fe, November 19.

. 2005c. "World-Systems, Borders, Boundaries, and Frontiers: An Exploration." Paper Presented at American Sociological Association Meeting, Philadelphia, August 14.

. 2006a. "Comparing the Incomparable: Frontiers in World Historical Perspective." Paper Presented at American Historical Association, Philadelphia, January 7.

. 2006b. "[Re] Periphalization, [Re]Incorporation, Frontiers, and Nonstate Societies: Continuities and Discontinuities in Globalization Processes.” Pp. 96-113 in Globalization and Global History edited by Barry K. Gills and William R. Thompson. London: Routledge.

Hall, Thomas D., Christopher Chase-Dunn and Richard Niemeyer. Forthcoming. "The Roles of Central Asian Middlemen and Marcher States in Afroeurasian World-System 
Synchrony." For inclusion in Political Economy of the World-System Vol XXXI, edited by Ganesh Trinchur. Boulder, CO: Paradigm Press.

Hall, Thomas D. and James V. Fenelon. 2003. "Indigenous Resistance to Globalization: What Does the Future Hold?" Pp. 173-188 in Emerging Issues in the 21st Century WorldSystem: Vol. I: Crises and Resistance in the 21st World-System, edited by Wilma A. Dunaway. Westport, CT: Praeger.

. 2004. "The Futures of Indigenous Peoples: 9-11 and the Trajectory of Indigenous Survival and Resistance." Journal of World-Systems Research,10:1(Winter):153-197.

. 2009. Indigenous Peoples and Globalization: Resistance and Revitalization. Boulder, CO: Paradigm Press.

Hall, Thomas D and Peter Turchin. 2007. "Lessons from Population Ecology for World-Systems Analyses of Long-Distance Synchrony." Pp. 74-90 in The World System and the Earth System: Global Socioenvironmental Change and Sustainability Since the Neolithic, edited by Alf Hornborg and Carole L. Crumley. Walnut Creek, CA: Left Coast Books.

Harff, Barbara and Ted Robert Gurr. 2004. Ethnic Conflict in World Politics. 2nd ed. Boulder, CO: Westview Press.

Hill, Jonathan D. 1996a. "Introduction: Ethnogenesis in the Americas, 1492-1992." Pp. 1-19 in History, Power, and Identity: Ethnogenesis in the Americas, 1492-1992, edited by Jonathan D. Hall. Iowa City: University of Iowa Press.

1996b. "Violent Encounters: Ethnogenesis and Ethnocide in Long-Term Contact Situations." Pp. 146-171 in in Studies in Culture Contact: Interaction, Culture Change, and Archaeology edited by James G. Cusick, Center for Archaeological Investigations Occasional Paper 25. Carbondale: Southern Illinois University.

Hofstadter, Richard and Lipset, Seymour Martin, eds. 1968. Turner and the Sociology of the Frontier. New York: Basic Books.

Hogan, Richard. 1990. Class \& Community in Frontier Colorado. Lawrence: University Press of Kansas.

Hollis, Shirley. 2004. "Crafting Europe's "Clean Slate" Advantage: World-System Expansion and the Indigenous Mississippians of North America." American Indian Culture and Research Journal 28:3:77-101.

. 2005. "Contact, Incorporation, and the North American Southeast." Journal of WorldSystems Research 11(1):95-130.

Kenner, Charles L. 1969. A History of New Mexican - Plains Indians Relations. Norman: University of Oklahoma Press.

Klein, Kerwin Lee. 1996. "Reclaiming the 'F' Word, Or Being and Becoming Postwestern." Pacific Historical Review 65:2:179-215.

Lamar, Howard R. and Thompson, Leonard, eds. 1981. The Frontier in History: North America and Southern Africa Compared. New Haven: Yale University Press.

Lamont, Michèle and Virág Molnár. 2002. "The Study of Boundaries in the Social Sciences." Annual Review of Sociology 28:167-195.

Lattimore, Owen. 1951. Inner Asian Frontiers, 2nd ed. Boston: Beacon Press. 1962a. "The Frontier in History." Pp. 469-491 in Lattimore (1962c). . 1962b. "Inner Asian Frontiers: Defensive Empires and Conquest Empires." Pp. 501-513 in Lattimore (1962c). 


\section{PUZZLES IN THE COMPARATIVE STUDY OF FRONTIERS 46}

1962c. Studies in Frontier History: Collected Papers, 1928-58. London: Oxford University Press.

. 1980. "The Periphery as Locus of Innovation." Pp. 205-208 in Jean Gottman, ed., Centre and Periphery: Spatial Variation in Politics. Beverly Hills: Sage.

Lecompte, Janet. 1985. Rebellion in Río Arriba, 1837. Albuquerque: University of New Mexico Press.

Lightfoot, Kent G. and Antionette Martinez. 1995. "Frontiers and Boundaries in Archaeological Perspective." Annual Review of Anthropology 24:471-492.

Limerick, Patricia Nelson. 1987. The Legacy of Conquest: The Unbroken Past of the American West. New York: Norton.

Limerick, Patricia Nelson, Clyde A. Milner, and Charles Rankin, eds. 1991. Trails: Toward A New Western History. Lawrence: University Press of Kansas.

Luttwak, Edward N. 1976. The Grand Strategy of the Roman Empire: From the First Century A.D. to the Third. Baltimore: Johns Hopkins Univeristy Press.

Martin, Paul S. and Christine R. Szuter. 1999. "War Zones and Game Sinks in Lewis and Clark's West." Conservation Biology 13(1):36-45.

McMichael, Philip. 1990. "Incorporating Comparison within a World-Historical Perspective: An Alternative Comparative Method." American Sociological Review 5(3):385-397.

McNeill, William H. 1964. Europe's Steppe Frontier, 1500-1800. Chicago: University of Chicago Press.

Parker, Bradley J. and Lars Rodseth, eds. 2005. Untaming the Frontier in Anthropology, Archaeology, and History. University of Arizona Press, Tucson.

Pirsig, Robert M. 1974. Zen and the Art of Motorcycle Maintenance: An Inquiry into Values. New York: William Morrow and Company.

Power, Daniel and Naomi Standen, eds. 1999. Frontiers in Question: Eurasian Borderlands, 7001700. New York: St. Martin's Press.

Ragin, Charles. 1987. The Comparative Method: Moving Beyond Qualitative and Quantitative Strategies. Berkeley, CA: University of California Press. 2000. Fuzzy-Set Social Science. Chicago: University of Chicago Press.

Reséndez, Andrés. 2005. Changing National Identities at the Frontier: Texas and New Mexico, 1800-1850. Cambridge, Cambridge University Press.

Rice, Prudence M. 1998. "Contexts of Contact and Change: Peripheries, Frontiers, and Boundaries." Pp. 44-66 in Studies in Culture Contact: Interaction, Culture Change, and Archaeology edited by James G. Cusick, Center for Archaeological Investigations Occasional Paper 25. Carbondale: Southern Illinois University.

Rice, Prudence M. and Don S. Rice. 2005. "The Final Frontier of the Maya:XXCentral Peten, Guatemala, A.D. 1450-1700." Pp. 147-173 in Untaming the Frontier in Anthropology, Archaeology, and History, edited by Bradley J. Parker and Lars Rodseth. University of Arizona Press, Tucson.

Robbins, William G. 1994. Colony and Empire: The Capitalist Transformation of the American West. Lawrence, KS: University Press of Kansas.

Robinson, William I. 2004. A Theory of Global Capitalism. Baltimore: MD. Johns Hopkins University Press.

Sanderson, Stephen K. 1999. Social Transformations: A General Theory of Historical Development, expanded edition. Lanham, MD: Rowman and Littlefield. 


\section{JOURNAL OF WORLD-SYSTEMS RESEARCH}

Sanderson, Stephen K. and Arthur S. Alderson. 2005. World Societies: The Evolutional of Human Social Life. Boston: Pearson, Allyn \& Bacon.

Skinner, G. William. 1985. Presidential Address: "The Structure of Chinese History." Journal of Asian Studies 64(2):271-292.

Sklair, Leslie. 2002. Globalization: Capitalism and Its Alternatives, 3rd ed. Oxford: Oxford University Press.

Slatta, Richard W. 1990. Cowboys of the Americas. New Haven: Yale University Press. . 1997. Comparing Cowboys and Frontiers. Norman: University of Oklahoma Press. 1998. "Spanish Colonial Military Strategy and Ideology." Pp, 83-96 in Contested Ground: Comparative Frontiers on the Northern and Southern Edges of the Spanish Empire, edited by Donna Guy and Thomas Sheridan. Tucson: University of Arizona Press. . 2001. "Taking Our Myths Seriously." Journal of the West 40(3):3-5.

. 2003. "The Whys and Wherefores of Comparative Frontier History." Journal of the West 42(1):8-13.

. 2007. "Introduction: Teaching the West." Journal of the West 46(2):10-13.

Smith, Adam T. and Karen S. Rubinson, eds. 2003. Archaeology in the Borderlands: Investigations in Caucasia and Beyond. Los Angeles: Cotsen Institute of Archaeology.

Snyder, David and Edward L. Kick. 1979. "Structural Position in the World System and Economic Growth, 1955-1970: A Multiple-Network Analysis of Transnational Interactions." American Journal of Sociology 84:1096-1126.

Stinchcombe, Arthur. 1978. Theoretical Methods in Social History. New York: Academic Press.

Turchin, Peter. 2008. "Modeling Periodic Waves of Integration in the Afroeurasian WorldSystem." Pp. xx-yy in Globalization as an Evolutionary Process: Modeling Global Change, edited by George Modelski, Tessaleno Devezas, William R. Thompson, editors. London: Routledge.

Taylor, George R., ed. 1972. The Turner Thesis: Concerning the Role of the Frontier in American History. Third ed. Lexington, MA: D. C. Heath.

Turchin, Peter and Thomas D. Hall. 2003. "Spatial Synchrony among and within World-Systems: Insights from Theoretical Ecology." Journal of World-Systems Research 9(1):37-64.

Weber, David J. 1986. "Turner, the Boltonians, and the Borderlands." American Historical Review 91(1):66-81.

2005. Bárbaros: Spaniards and Their Savages in the Age of Enlightenment. New Haven: Yale University Press.

Weber, David J. and Jane M. Rausch.1994. Where Cultures Meet: Frontiers in Latin American History. Wilmington, DE: Scholarly Resources Inc.

Whitehead, Neil L. ed. 2004a. Violence. Santa Fe, NM: School of American Research. . 2004b. Introduction: Cultures, Conflicts, and the Poetics of Violent Practice." Pp. 2-23 in Violence, edited by Neil L. Whitehead. Santa Fe, NM: School of American Research. 